\title{
PENERAPAN MODEL OPEN ENDED UNTUK MENINGKATKAN KETERAMPILAN PROSES DAN HASIL BELAJAR SISWA KELAS V SDN 1 REPAKING - WONOSEGORO - BOYOLALI
}

\author{
Betty Biliya A \\ SD Negeri 1 Repaking, Wonosegoro, Boyolali
}

\begin{abstract}
ABSTRAK
Tujuan Penelitian ini adalah untuk mendeskripsikan langkah-langkah pembelajaran Open Ended yang dapat meningkatkan keterampilan proses dan hasil belajar pada subtema Peristiwa-peristiwa Penting pada siswa kelas V SD Negeri 1 Repaking. Penelitian yang digunakan termasuk penelitian tindakan kelas, yang terdiri dari dua siklus. Masing-masing siklus terdiri atas tahapan perencanaan tindakan, pelaksanaan tindakan, observasi, dan refleksi. Instrumen pengumpulan data menggunakan rubrik penilaian keterampilan proses dan soal tes untuk muatan Bahasa Indonesia dan muatan Matematika. Analisis data dilakukan dengan menggunakan analisis deskriptif komparatif yaitu membandingkan kondisi awal sebelum dilakukan tindakan, hasil siklus 1, dan siklus 2. Hasil penelitian menunjukkan temuan bahwa model pembelajaran Open Ended dilakukan dengan integrasi penilaian autentik dapat: a) meningkatkan keterampilan proses pembelajaran siswa kelas V SD Negerei 1 Repaking, WonosegoroBoyolali. Presentase kenaikan ketermapilan proses sub tema Peristiwaperistiwa Penting sebesar 26,14\% untuk siklus I dan 31,59\% untuk siklus II. b) Meningkatkan persentase jumlah siswa yang mencapai ketuntasan belajar siswa kelas V SD Negeri 1 Repaking pada sub tema Peristiwa- peristiwa Penting untuk muatan Bahasa Indonesia sebagai berikut: pada kondisi awal, presentase pencapaian KKM sebesar 50\% (12 siswa), pada siklus I presentase meningkat menjadi 66,67\% (16 siswa), dan pada siklus II presentase meningkat mencapai $83,33 \%$ (20 siswa). Untuk muatan Matematika sebagai berikut: pada kondisi awal, presentase pencapaian KKM sebesar 37,5\% (9 siswa), pada siklus I presentase meningkat menjadi $58,33 \%$ (14 siswa), dan pada siklus II presentase meningkat mencapai 75\% (18 siswa).
\end{abstract}

Kata kunci: keterampilan proses, hasil belajar, model pembelajaran Open Ended.

\section{PENDAHULUAN}

Peraturan Pemerintah Nomor 32 Tahun 2013 tentang Standar Pendidikan Nasional terkait Standar proses bahwa proses pembelajaran pada satuan pendidikan diselenggarakan secara interaktif, inspiratif, menyenangkan, menantang, memotivasi peserta didik untuk berpartisipasi aktif, serta memberikan 
ruang yang cukup bagi prakarsa, kreativitas, dan kemandirian sesuai dengan bakat, minat, dan perkembangan fisik serta psikologis peserta didik. Untuk itu setiap satuan pendidikan melakukan perencanaan pembelajaran, pelaksanaan proses pembelajaran serta penilaian proses pembelajaran untuk meningkatkan efisiensi dan efektivitas ketercapaian kompetensi lulusan. Berdasarkan regulasi tersebut perlu adanya partisipasi aktif siswa, kreativitas dan kemandirian dalam pembelajaran untuk tercapainya kompetensi kelulusan. Oleh karena itu, diperlukan upaya untuk menciptakan pembelajaran secara interaktif dan menyenangkan bagi siswa dengan bimbingan guru.

Kurikulum 2013 mengakomodir keseimbangan antara soft skils dan hard skills yang meliputi aspek kompetensi sikap, ketrampilan, dan pengetahuan. Kompetensi dikembangkan melalui pembelajaran tematik integratik yang dilaksanakan dengan pendekatan sains. Pembelajaran tematik integratik diberlakukan di seluruh kelas di sekolah dasar, yang meliputi seluruh mata pelajaran yang disajikan secara terpadu dengan tema sebagai pemersatu.

Proses pembelajaran dalam kurikulum 2013 harus menampakkan proses pembelajaran yang memungkinkan siswa berlatih mengembangkan pendekatan saintifik, yang akan berdampak pada meningkatnya hasil belajar siswa. Namun dalam kenyataannya di SD Negeri 1 repaking pembelajaran yang dilaksanakan masih konvensional belum menerapkan model pembelajaran yang mampu meningkatkan keterampilan proses membuat siswa belum mampu mengembangkan materi seperti yang diharapkan. Hal ini berpengaruh terhadap hasil belajar siswa. Hasil belajar merupakan apa yang diperoleh siswa setelah dilakukan aktivitas belajar (Djamarah dan Zain, 2006:10).

Data hasil pengamatan awal terhadap keterampilan proses pembelajaran siswa kelas V SD Negeri 1 Repaking menunjukkan hanya 4 siswa $(16,67 \%)$ menunjukkan keterampilan prosespada kategor tinggi, 9 siswa $(37,5 \%)$ pada kategori sedang dan 11 siswa ( 45,83\%) pada kategori rendah. Oleh karena itu peneliti perlu mengkaji dan meneliti lebih mendalam rendahnya keterampilan proses dalam pembelajaran siswa kelas V SDN 1 Repaking Wonosegoro.

Rendahnya keterampilan proses dalam pembelajaran berdampak pada hasil belajar siswa. Data ketuntasan hasil belajar di atas KKM 68 untuk muatan Bahasa Indonesia baru mencapai 50\% (12 siswa) dan 37,5\% (9 siswa) untuk muatan Matematika.

Untuk mengatasi hal tersebut guru sebagai tenaga pengajar dan pendidik harus selalu meningkatkan kualitas pengajaran dan pembelajaran di kelas yaitu, dengan melibatkan siswa secara aktif dan efektif dalam proses belajar mengajar sesuai dengan penerapan kurikulum 2013. Salah satunya dengan model pembelajaran Open Ended, model pembelajaran yang menyajikan suatu 
permasalahan yang memiliki metode atau penyelesaian yang benar lebih dari satu, sehingga dapat memberi kesempatan kepada siswa untuk memperoleh pengetahuan/pengalaman menemukan, menggali, dan memecahkan masalah dengan beberapa teknik.

Melalui model Open Ended diharapkan di kelas siswa aktif dalam belajar, aktif berdiskusi, berani menyampaikan gagasan dan menerima gagasan orang lain, kreatif dalam mencari solusi dari suatu permasalahan.

Berdasarkan uraian di atas, permasalahan penelitian yang akan dipecahkan dalam PTK ini adalah apakah model pembelajaran Open Ended dapat meningkatkan keterampilan prosesdan hasil belajar siswa tersebut bisa tercapai.

\section{KAJIAN PUSTAKA}

\section{Hakikat Pembelajaran Tematik Integratif}

Junaidi Arsyad, Ahmad Syukur, M.Toguan,Suhaiman dan Nurbaiti (2014 : 5) Integrated Model adalah model pengembangan kurikulum yang menggunakan pendekatan lintas bidang ilmu utama dengan mencari keterampilan, konsep dan sikap yang tumpang tindih. Dalam konteks pembelajaran TK, Integrated Model adalah model pengembangan kurikulum yang menggunakan pendekatan lintas bidang pengembangan. Model ini berusaha memberikan gambaran yang utuh pada anak tentang tujuan melakukan kegiatan-kegiatan yang terdapatdalam bidangbidang pengembangan.

Ahsana, Eka Anisyah, Husnaeni (2013: 4) Pembelajaran tematik adalah pembelajaran terpadu yang menggunakan tema untuk mengaitkan beberapa mata pelajaran sehingga dapat memberikan pengalaman bermakna kepada siswa. Pembelajaran tematik dapat diartikan suatu kegiatan pembelajaran dengan mengintegrasikan materi pelajaran dalam suatu tema/topik pembahasan.

Hosnan (2014:364) pembelajaran tematik lebih menekankan pada keterlibatan siswa dalam proses pembelajaran, sehingga siswa dapat memperoleh pengalalaman langsung dan terlatih untuk dapat menemukan sendiri berbagzai pengetahuan yang dipelajarinya.

Berdasarkan beberapa pendapat diatas dapat disimpulkan bahwa pembelajaran tematik integratif merupakan pengembangan kurikulum yang menggunakan tema untuk mengaitkan beberapa mata pelajaran untuk mengintegrasikan pengetahuan, keterampilan, nilai atau sikap pembelajaran dengan menekankan keterlibatan siswa dalam proses pembelajaran.

Pembelajaran tematik integratif terpadu diajarkan berdasarkan tahapan tertentu. Menurut Pelatihan Implementasi Kurikulum 2013 (Kemendikbud, 2014:17) disebutkan ada beberapa tahapan dalam pembelajaran tematik integratif 
yaitu pertama guru harus mengacu pada tema sebagai pemersatu berbagai muatan pelajaran untuk satu tahun. Kedua guru melakukan analisis Standar Kompetensi Lulusan, kompetensi inti, kompetensi dasar dan membuat indikator dengan tetap memperhatikan muatan pelajaran. Cakupan KD pada sub tema Peristiwa-peristiwa Penting adalah sebagai berikut:

1) 1) Cakupan $K D$ pada muatan Bahasa Indonesia

2) 3.2 Menguraikan isi teks penjelasan tentang proses daur air, rangkaian listrik, sifat magnet, anggota tubuh (manusia, hewan, tumbuhan) dan fungsinya, serta sistem pernapasan bantuan guru dan teman dalam bahasa Indonesia lisan dan tulis dengan memilih dan memilah kosa kata baku

- Menguraikan isi teks tentang daur air

3) 4.2 Menguraikan isi teks penjelasan tentang proses daur air, rangkaian listrik, sifat magnet, anggota tubuh (manusia, hewan, tumbuhan) dan fungsinya, serta sistem pernapasan bantuan guru dan teman dalam bahasa Indonesia lisan dan tulis dengan memilih dan memilah kosa kata baku

- Menjelaskan daur air dengan menggunakan gambar atau diagram.

2) Cakupan KD pada muatan Matematika

4) 3.3 Memilih prosedur pemecahan masalah dengan menganalisis hubungan antar simbol, informasi yang relevan, dan mengamati pola.

- Menyajikan pernyataan matematika secaralisan, tertulis, dan diagram

- Menggunakan cara induktif dalam mengenal atau memprediksi suatu pola

5) 4.3 Menunjukkan kesetaraan menggunakan perkalian atau pembagian dengan jumlah nilai yang tidak diketahui pada kedua sisi

- Menunjukkan kesetaraan menggunakan perkalian dengan jumlah nilai yang tidak diketahui pada kedua sisi

Karakteristik pembelajaran tematik integratif, yaitu berpusat pada siswa, memberikan pengalaman langsung, pemisahan mata pelajaran tidak begitu jelas, menyajikan konsep dari berbagai mata pelajaran, bersifat fleksibel, hasil pembelajaran sesuai dengan minat dan kebutuhan siswa serta menggunakan prinsip belajar sambil bermain dan menyenangkan. Merupakan pembelajaran yang dipadankan dengan suatu proses ilmiah yaitu melalui pendekatan saintifik.

Seperti yang telah diuraikan diatas, maka guru perlu mempertimbangkan rancangan tentang keterampilan proses, memberikan pengalaman autentik pada 
Penerapan Model Open Ended untuk Meningkatkan Keterampilan Proses dan Hasil Belajar Siswa Kelas V (Betty Biliya. A)

siswa, menerapkan model pembelajaran misal Open Ended dan merancang penilaian yang dapat mengukur proses secara autentik misalnya penilaian autentik. Uraian secara mendalam tentang keterampilan proses, Open Ended, dan penilaian autentik pada bagaian tersendiri.

\section{Hakikat Pendekatan Saintifik}

Hosnan (2014:34) mengemukakan bahwa Implementasi kurikulum 2013 dalam pembelajaran dengan pendekatan saintifik adalah proses pembelajaran yang dirancang sedemikian rupa agar peserta didik secara aktif mengonstruk konsep, hukum atau prinsip melalui tahapan-tahapan mengamati, merumuskan masalah, mengajukan atau merumuskan hipotesis, mengumpulkan data dengan berbagai tehnik, menganalisis data, menarik kesimpulan dan mengkomunikasikan konsep, hukum atau prinsip yang "ditemukan".

Menurut Pelatihan Implementasi Kurikulum 2013 ( Kemendikbud, 2014:18) pendekatan saintifik diyakini sebagai titian emas perkembangan dan pengembangan sikap, keterampilan, dan pengetahuan peserta didik. Dalam pendekatan atau proses kerja yang memnuhi kriteria ilmiah, para ilmuwan lebih mengedepankan penalaran induktif dibandingkan penalaran deduktif.

Langkah-langkah pendekatan saintifik dalam proses pembelajaran pada Kurukulum 2013 meliputi: menggali informasi melalui mengamati, menanya, mengolah data atau informasi, menganalisis data (mengasosiasi) kemudian mengkomunikasikan.

\section{Keterampilan Proses}

Menurut Wahyudi \& Kriswandani (2010: 53) Keterampilan proses merupakan kegiatan belajar mengajar yang berfokus pada penelitian siswa secara aktif dan kreatif dalam proses memperoleh hasil belajar. Hasil belajar yang diperoleh siswa tidak hanya terbatas pada aspek pengetahuan saja melainkan bagaimana proses mencapai tujuan pembelajaran yang diharapkan dapat terpenuhi.

Nyimas Aisyah (2008:5) menyebutkan prinsip-prinsip keterampilan proses matematika meliputi: 1) mengamati, yaitu kegiatan yang terarah untuk menangkap gejala atau fenomena sehingga mampu membedakan yang sesuai dan yang tidak sesuai dengan pokok permasalahan menggunakan indera secara optimal dalan rangka memperoleh informasi yang lengkap atau memadai. 2) menghitung, merupakan keterampilan dasar yang digunakan dalam kehidupan sehari-hari. Hasil dari perhitungan dapat disajikan dalam bentuk tabel, grafit dan atau histogram. 3) mengukur, merupakan keterampilan dimana seseorang dapat mengetahui sesuatu 
yang diamati dengan mengukur apa yang diamatinya. 4) mengklasifikasi, merupakan kemampuan mengelompokkan atau menggolongkan sesuatuyang berupa benda, informasi, fakta dan gagasan. 5) memenukan hubungan, merupakan kemampuan menentukan hubungan antara sikap dan tindakan yang sesuai. 6) membuat prediksi, merupakan kemampuan menyusun hipotesis atau suatu perkiraan untuk menerangkan suatu kejadian atau pengamatan tertentu. 7) melaksanakan penelitian, merupakan kegiatan penyelidikan untuk menguji gagasan-gagasan melalui kegiatan eksperimen praktis. 8) mengumpulkan dan menganalisis data, merupakan kemampuan mengenai bagaimana cara-cara mengumpulkan data dalam penelitian baik kuantitatif maupun kualitatif. 9) menginterprestasikan data, merupakan kemampuan untuk menafsirkan data yang telah dikumpulkan dari berbagai kegiaan. 10) mengkomunikasikan hasil, merupakan kegiatan untuk mengkomunikasikan proses dari hasil perolehan kepada berbagai pihak yang berkepentingan, baik dalam bentuk kata-kata, grafik, bagan maupun tabel secara lisan maupun tertulis.

Keterampilan proses Bahasa Indonesia meliputi, 1) mengamati, 2) menggolongkan, 3) menafsirkan, 4) menerapkan, 5) mengkomunikasikan. Berdasarkan keterampilan proses pada muatan Matematika dan Bahasa Indonesia diatas, peneliti mengambil keterampilan yang sesuai dengan materi subtema Peristiwa-peristiwa Penting sebagai berikut: 1) mengamati, 2) merumuskan masalah, 3) mengklasifikasikan, 4) mengumpulkan data, 5) menganalisis data, 6) menemukan hubungan, 7) menghitung, 8) menarik kesimpulan, 9) mengkomunikasikan, 10). meringkas

\section{Model Pembelajaran Open Ended}

Menurut Shimada (Arsad HS, Dwi NS, Winanda Marito, 2013: 1) model Open Ended adalah suatu pendekatan pembelajaran yang dimulai dari mengenal atau menghadapkan siswa pada masalah terbuka. Pembelajaran dilanjutkan dengan menggunakan banyak jawaban yang benar dari masalah yang diberikan untuk memberikan pengalaman kepada siswa dalam menemukan sesuatu yang baru di dalam proses pembelajaran.

Model Open Ended adalah pembelajaran yang menyajikan suatu permasalahan yang memiliki metode atau penyelesaian yang benar lebih dari satu. Menurut Suherman (2003:123) problem yang diformulasikan memiliki multi jawaban yang benar disebut problem tak lengkap atau disebut juga Open Ended problem atau soal terbuka.

Tujuan dari pembelajaran Open Ended menurut Nohda (Suherman, 2003:124) ialah untuk membantu mengembangkan kegiatan kreatif dan pola pikir matematik siswa melalui problem posing secara simultan. Dengan kata lain, 
kegiatan kreatif dan pola matematik siswa harus dikembangkan semaksimal mungkin sesuai dengan kemampuan setiap siswa. Adapun langkah-langkah atau sintak Open Ended meliputi pemberian masalah, memahami masalah, pemecahan masalah, membandingkan dan mediskusikan, menyimpulkan dan opsinal.

Dalam pendekatan Open Ended guru memberikan permasalahan kepada siswa yang solusinya tidak hanya ditentukan hanya dengan satu jalan atau cara. Guru harus memanfaatkan keberagaman cara untuk menyelesaikan masalah itu untuk memberikan pengalaman siswa dalam menemukan sesuatu yang baru berdasarkan pengetahuan, keterampilan dan cara berpikir yang telah diperoleh sebelumnya. Keunggulan dari pendekatan ini antara lain: 1) siswa berpartisipasi lebih aktif dalam pembelajaran dan sering mengekspresikan idenya. 2) siswa memiliki kesempatan lebih banyak dalam memmanfaatkan pengetahuan dan keterampilan matematik secara komprehensif. 3) siswa dengan kemampuan matematika rendah dapat merespon permasalahan dengan cara mereka sendiri. 4) siswa secara instringsik termotivasi untuk memberikan bukti atau penjelasan. 5) siswa memiliki pengalaman lebih banyak untuk menemukan sesuatu dlam menjawab permasalahan. Disamping keunggulan yang dapat diperoleh dari pendekatan Open Ended terdapat kelemahan diantaranya: 1) membuat dan menyiapkan permasalahan matematik yang bermakna bagi siswa bukanlah pekerjaan yang mudah. 2) mengemukakan masalah yang langsung dapat dipahami siswa sangat sulit. 3) siswa dengan kemampuan tinggi bisa meragu dengan jawaban mereka. 4) mungkin sebagian siswa merasa bahwa kegiatan belajar mereka tidak menyenangkan karena kesulitan yang dihadapi.

Berdasarkan hakikat pembelajaran tematik, karakteristik pembelajaran tematik seperti yang telah diuraikan diatas, maka model Open Ended dapat dijadikan salah satu alternatif model pembelajaran tematik di SD. Implementasi model Open Ended, secara teoritik dapat meningkatkan keterampilan proses tematik siswa yang nantinya akan berdampak pada penguasaan konsep-konsep tematik. Berbagai penelitian tindakan membuktikan potensi model Open Ended secra empirik. Dedy Widoyo (2014) meneliti tentang penerapan Open Ended di kelas VA SD Muhamadiyah 1 Panarukan Tahun Pelajaran 2013/2014 menemukan hasil bahwa model Open Ended dapat meningkatkan aktivitas dan hasil belajar dalam pelajaran ips pokok bahasan suku bangsa dan budaya. Dewi, Afry Pusvita (2013) melakukan penelitian dan menemukan hasil bahawa penerapan model Open Ended dapat meningkatkan hasil belajar matematika siswa pada materi jaring-jaring balok dan kubus kelas IV SDN Wonoketingal 1. Nadhifatul Umala (2012) melakukan PTK dengan mengimplementasikan model Open Ended dan menemukan hasil bahwa implementasi Model Open Ended dapat 
meningkatkan prestasi dan kemampuan berpikir kritis peserta didik XI IPA MAN Kunir Kabupaten Blitar.

Uraian tentang hakikat Open Ended dan temuan berbagai penilitian di atas berimplikasi pada desain pembelajaran dan penilaian pembelajaran. Penilaian tidak cukup dengan tes melainkan melalui penilaian autentik yang mencakup ranah sikap, keterampilan, dan pengetahuan. Uraian tentang penilaian autentik dalam pembelajaran tematik akan dibahas pada bagian selanjutnya. Tujuan dari model Open Ended untuk membantu mengembangkan kegiatan kreatif dan pola pikir matematik siswa melalui problem posing secara simultan sesuai kemampuan siswa sendiri.

Mencermati uraian tentang sintak model Open Ended seperti diatas, sebenarnya Open Ended dapat digunakan sebagai sarana pendekatan saintifik. Langkah orientasi pemberian masalah dilakukan dengan cara mengamati gambar dan permasalahan dalam pembelajaran tematik. Kegiatan menanya sejalan dengan aktivitas memahami masalah dalam pembelajaran. Kegiatan pembelajaran dengan melakukan pemecahan masalah, kemudian dilanjutkan dengan kegiatan menbandingkan dan berdiskusi kelompok dalam sintak Open Ended relevan mengumpulkan data dan mengasosiasikan. Kegiatan menyimpulkan dan opsinal merupakan kegiatan yang relevan dengan kegiatan mengkomunikasikan dalam pendekatan saintifik.

Kesepadanan sintak Open Ended dengan keterampilan proses ilmiah dalam pendekatan saintifik nampaknya relevan dengan keterampilan proses dalam pembelajaran subtema Peristiwa-peristiwa Penting. Kegiatan mengamati dalam keterampilan proses sejalan dengan proses mengamati dalam pendekatan saintifik dan kegiatan pemberian masalah dalam Open Ended. Kegiatan merumuskan masalah dalam keterampilan proses sejalan dengan kegiatan memahami masalah dalam Open Ended. Kegiatan pemecahan masalah dalam keterampilan proses sejalan dengan kegiatan mengklasifikasikan dan mengumpulkan data. Kegiatan membandingkan dan mendiskusikan dalam sintak Open Ended merupakan kegiatan yang relevan dengan kegiatan menganalisis data, menemukan hubungan, dan menghitung. Kegiatan menyimpulkan dalam langkah Open Ended berhubungan dengan kegiatan menarik kesimpulan dan mengkomunikasikan dalam keterampilan proses. Kegiatan opsinal dalam langkah Open Ended sejalan dengan kegiatan meringkas dalam keterampilan proses.

\section{Penilaian Autentik}

Penilaian autentik adalah suatu istilah/terminologi yang diciptakan untuk menjelaskan berbagai metode penilaian alternatif yang memungkinkan siswa 
Penerapan Model Open Ended untuk Meningkatkan Keterampilan Proses dan Hasil Belajar Siswa Kelas V (Betty Biliya. A)

dapat mendemonstrasikan kemampuannya dalam menyelesaikan tugas-tugas dan menyelesaikan masalah (Kemdikbud, 2014: 34).

Menurut Hosnan (2014:387) mendefinisikan penilaian autentik sebagai pengukuran yang bermakna secara signifikan atas hasil belajar peserta didik untuk ranah sikap, keterampilan, dan pengetahuan

Dari pendapat diatas dapat disimpulkan penilaian autentik yaitu pengukuran hasil belajar siswa untuk kegiatan demontrasi kemampuan, ranah sikap, keterampilan dan pengetahuan.

Hosnan (2014:396) mengungkapkan bahwa teknik penilaian autentik terdiri dari tiga aspek penilaian yaitu: 1) penilaian sikap, penilaian yang dilakukan menggunakan lembar observasi kinerja saat siswa bekerja kelompok, bekerja individu, berdiskusi maupun saat presentasi menggunakan. 2) penilaian pengetahuan, penilaian yang dilakukan menggunakan instrumen tes tertulis, instrumen tes lisan dan instrumen penugasan. 3) penilaian proses atau keterampilan, penilaian yang dilakukan menggunakan penilaian kinerja melalui tes praktik, projek, dan penilaian portofolio.

\section{Kerangka Berpikir}

Temuan awal dalam pembelajaran di kelas V SD Negeri 1 Repaking menunjukkan bahwa keterampilan proses pembelajaran masih rendah hal ini berdampak pada hasil belajar siswa yang rendah. Hal ini dkarenakan proses pembelajaran yang masih konvensional belum menggunakan model pembelajaran yang sesuai dengan materi.

Oleh karena itu tindakan yang dilakukan peneliti untuk mengatasi masalah tersebut, yaitu dengan menerapkan model pembelajaran yang sesuai dengan materi yang diajarkan dalam proses pembelajaran. Salah satunya dengan menerapkan model Open Ended yang dapat mengembangkan kegiatan kreatif dan pola pikir matematik siswa sehingga akhirnya dapat meningkatkan keterampilan proses dan hasil belajar siswa.

\section{METODE PENELITIAN}

Penelitian tindakan kelas dilaksanakan di SD Negeri 1 Repaking Wonosegoro Boyolali pada tema 2 subtema Peristiwa-peristiwa Penting semester I tahun pelajaran 2014/2015. Penelitian ini dilakukan dalam dua siklus. Siklus I dilaksanakan pada September minggu kedua dan siklus II dilaksanakan minggu ketiga bulan September. Subjek yang dilibatkan dalam penelitian tindakan kelas ini adalah siswa kelas $\mathrm{V}$ yang berjumlah 24 siwa, yang terdiri dari 11 laki- laki dan 13 perempuan. 
Sumber data primer berasal dari hasil pengukuran variabel penelitian tindakan kelas sebagai berikut: 1) nilai hasil belajar siswa ,2) nilai keterampilan proses siswa dalam pembelajaran. Sumber data sekunder berasal dari hasil pengamatan teman sejawat terhadap aktivitas pembelajaran yang terdiri dari: 1) aktivitas guru dan 2) aktivitas siswa dalam pembelajaran.

Teknik pengumpulan data dalam penelitian ini menggunakan teknik tes dan non tes. Instrumen tes dan non tes berupa: 1) instrumen pengumpulan data hasil belajar menggunakan tes hasil belajar, 2) instrumen pengumpulan data mengenai keterampilan proses menggunakan rubrik penilaian keterampilan proses. Validitas data menggunakan triangulasi sumber dan triangulasi metode.

Analisis data yang digunakan adalah teknik analisis deskriptif komparatif. Data yang diperoleh di deskripsikan dalam bentuk kata-kata atau penjelasan. Baik data yang diperoleh dari hasil belajar siswa maupun rubrik penilaian keterampilan proses. Selanjutnya dilakukan komparasi data setiap siklus untuk memastikan adanya peningkatan keterampilan saintintifik dan hasil belajar siswa. Sebagai tolak ukur keberhasilan penelitian tindakan kelas ini ditetapkan indikator kinerja sebagai berikut: 1) presentase jumlah siswa yang mencapai KKM sebesar 50\% untuk siklus I, dan $70 \%$ untuk siklus II; meningkatnya keterampilan proses sebesar $15 \%$ untuk setiap siklus.

Suharsimi Arikunto (2009:16), mengemukakan bahwa model penelitian tindakan kelas meliputi empat tahapan, yaitu (1) perencanaan, (2) pelaksanaan,(3) pengamatan, dan 4) refleksi.

\section{HASIL DAN PEMBAHASAN}

\section{Deskripsi Hasil Tiap Siklus dan Antar Siklus}

Setelah dilaksanakan analisis data disetiap siklus, maka dapat disimpulkan bahwa penerapan model pembelajaran Open Ended dapat meningkatkan keterampilan proses dan ketuntasan hasil belajar siswa pada subtema Peristiwa-peristiwa Penting. Tabel 1 merangkum komparasi tingkat keterampilan proses dari kondisi awal, siklus I, dan siklus II.

Tabel 1. Komparasi Tingkat Keterampilan Proses

\begin{tabular}{|c|c|c|}
\hline \multirow{2}{*}{ Pembelajaran } & \multicolumn{2}{|c|}{ Tingkat Keterampilan Proses } \\
\cline { 2 - 3 } & Mean & \% Kenaikan \\
\hline Kondisi Awal & 22,40 & - \\
\hline Siklus I & 26,14 & 16,69 \\
\hline Siklus II & 31,59 & 20,85 \\
\hline
\end{tabular}

Dari data dalam Tabel 1, diperoleh temyan: a) kondisi awal, rata-rata ringkat keterampilan proses pembelajaran siswa baru 22,40 (skor maksimal 40); 
Penerapan Model Open Ended untuk Meningkatkan Keterampilan Proses dan Hasil Belajar Siswa Kelas V (Betty Biliya. A)

b) pada siklus I, rata-rata keterampilan proses siswa mencapai 26,14. Capaian ini menunjukkan peningkatan sebesar $16,69 \%$ : c) pada siklus II, rata-rata keterampilan proses siswa mencapai 31,59. Capaian ini menunjukkan peningkatan sebesar 20,88

Kenaikan mean hasil belajar dan presentase jumlah ketuntasan belajar siswa dirangkum dalam Gambar 1. Dari Gambar 1diperoleh data sebagai berikut: a) pada kondisi awal,untuk muatan Bahasa Indonesia mean hasil belajar baru 62,08 , sedangkan presentase jumlah siswa yang mencapai KKM hanya 50\% (12 siswa). Muatan Matematika mean hasil belajar baru 55,83, sedangkan presentase jumlah siswa yang mencapai KKM hanya 37,5\% (9 siswa); b) pada siklus I, muatan Bahasa Indonesia mean hasil belajar menjadi 72,5 dan presentase meningkat menjadi 66,67\% (16 siswa). Untuk muatan Matematika mean hasil belajar menjadi 67,08 dan presentase meningkat menjadi 58,33 (14 siswa); c) pada siklus II, mean hasil belajar muatan Bahasa Indonesia meningkat menjadi 78,75 dan presentase jumlah siswa yang mencapai KKM meningkat menjadi 83,33 (20 siswa). Untuk muatan Matematika, mean hasil belajar meningkat menjadi 74,58 dan presentase jumlah siswa yang mencapai KKM meningkat menjadi $75 \%$ (18 siswa).

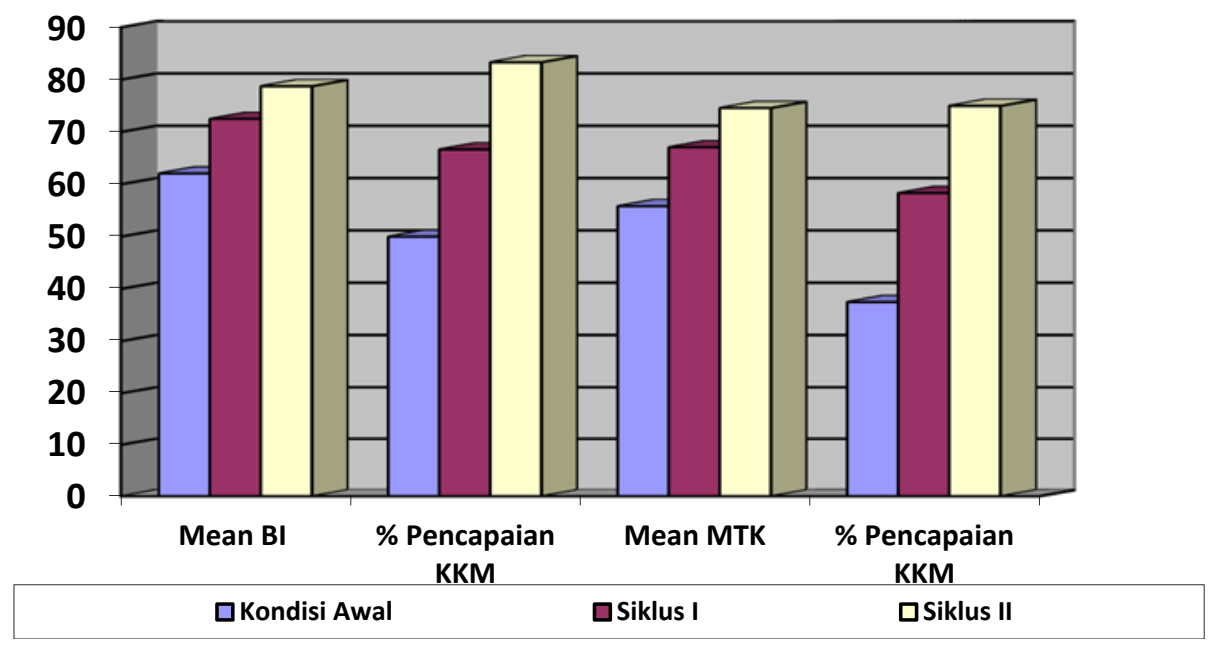

Gambar 1. Komparasi Mean dan Ketuntasan Hasil Belajar

\section{Temuan Penelitian dan Pembahasan}

1. Keberhasilan model Open Ended dalam meningkatkan keterampilan proses

Data pada tabel keterampilan proses kondisi awal, siklus 1 dan siklus 2 menunjukkan temuan rerata keterampilan prosespada kondisi awal 22,40 pada siklus I 26,14 dan pada siklus II 31,59. Temuan ini mengindikasikan 
adanya peningkatan tingkat keterampilan proses. Besaran peningkatan $16,69 \%$ pada siklus I dan 20,85\% pada siklus II. Jika dibandingkan dengan indikator kinerja $15 \%$ ternyata temuan siklus II tersebut telah mencapai keberhasilan

Keberhasilan penelitian ini bermakna bahwa siswa mampu mengamati, menanya, mengumpulkan informasi, mengasosiasi dan mengkomunikasikan. Temuan ini sejalan dengan penelitian Dedy Widoyo (2014) dan Nadhifatul Umala (2012).

\section{Keberhasilan Open Ended dalam meningkatkan hasil belajar siswa}

Data pada grafik 1 hasil belajar siswa kondisi awal, siklus I, dan siklus II menunjukkan temuan untuk muatan Bahasa Indonesia kondisi awal, mean 62,08, pada siklus I mean 72,5, pada siklus II mean 78,75. Temuan ini mengindikasikan adanya peningkatan hasil belajar siswa. Besaran peningkatan $66,67 \%$ pada siklus I dan 83,33 pada siklus II. Jika dibandingkan dengan indikator kinerja 50\% untuk siklus I, 70\% untuk siklus II ternyata siklus I dan siklus II tersebut telah mencapai keberhasilan.

Data pada grafik 1 hasil belajar siswa kondisi awal, siklus I, dan siklus II menunjukkan temuan untuk muatan Matematika kondisi awal, mean 55,83, pada siklus I mean 67,08, pada siklus II mean 74,58. Temuan ini mengindikasikan adanya peningkatan hasil belajar siswa. Besaran peningkatan 58,33\% pada siklus I dan $75 \%$ pada siklus II. Jika dibandingkan dengan indikator kinerja 50\% untuk siklus I, 70\% untuk siklus II ternyata siklus I dan siklus II tersebut telah mencapai keberhasilan.

Keampuhan model Open Ended mampu meningkatkan keterampilan proses dan hasil belajar siswa. Keampuhan ini terbuktinya dalam sintak/langkah pembelajaran, 1) sintak satu pemberian masalah pada siswa terbukti siswa mampu mengamati. 2) sintak kedua kemudian para siswa diajak membahas masalah dengan merumuskan masalah. 3) sintak ketiga melakukan pemecahan masalah siswa mengumpulkan informasi penting dari bacaan, mengidentifikasi informasi yang ada serta menghubungkan materi dengan muatan lain. 4) sintak ketiga selanjutnya kegiatan membandingkan dan mendiskusikan, siswa melakukan diskusi secara kelompok, menemukan hubungan antar muatandan melakukan kegiatan menghitung. Kegiatan berikutnya 5) sintak keempat menyimpulkan, yaitu siswa mampu menarik kesimpulan dan mengkomunikikasikan. 6) sintak kelima opsinal terbukti siswa mampu membuat ringkasan dari pembelajaran yang dilaksankan.

Temuan ini sejalan dengan penelitian Dewi Afry Pusvita (2013), Dedy Widoyo (2014) dan Nadhifatul Umala (2012). 


\section{SIMPULAN DAN SARAN}

\section{Simpulan}

Berdasarkan hasil penelitian dan pembahasan, dapat disimpulkan bahwa Model Pembelajaran Open Endeddan penilaian autentik dapat:

3. Meningkakan keterampilan proses pada siswa kelas V SD Negeri 1 Repaking, Kecamatan Wonosegoro, Kabupaten Boyolali. Besaran peningkatan pada siklus I 25,55 dan 31,59 pada siklus II

4. Meningkatkan hasil belajar siswa kelas V SD Negeri 1 Repaking Kecamatan Wonosegoro, Kabupaten Boyolali untuk muatan Bahasa Indonesia 66,67\% pada siklus I sedangkan pada siklus II sebesar 83,33\%. Muatan Bahasa Matematika 58,33\% pada siklus I dan pada siklus I sebesar 75\%.

\section{Saran}

Saran yang diajukan dalam penelitian ini adalah, para guru hendaknya: a) menggunakan model pembelajaran Open Ended dalam pembelajaran subtema Peristiwa-peristiwa Penting, b) melatih siswa untuk berpartisipasi aktif dalam pembelajaran di kelas dan c) mengembangkan keterampilan proses dalam pembelajaran.

\section{DAFTAR PUSTAKA}

Ahsana, Eka Anisyah, Husnaeni. 2013. Model Pembelajaran Tematik. Diambil dari http//www.academia.edu. Diakses tanggal 20 Oktober 2014

Arikunto, Suharsimi. 2009. Penelitian Tindakan Kelas. Jakarta. Rineka Cipta.

Arsad HS, Dwi NS, Winanda Marito. 2013. Pendekatan Open Ended Problem. Diambil dari http//www.academia.edu. Diakses tanggal 20 Oktober 2014

Dedy Widoyo. 2014. Penerapan Metode Open Ended Untuk Meningkatkan Aktivitas dan Hasil Belajar Siswa Dalam Pelajaran IPS Pokok Bahasan Suku Bangsa dan Budaya Kelas VA SD Myhamadiyah 1 Panarukan. Jember: Universitas Jember.

Dewi, Afry Pusvita. 2013. Meningkatkan Hasil Belajar Matematika Siswa MenggunakanPendekatan Open Ended Materi Jaring-jaring Balok dan Kubus Kelas IV SDN Wonoketingal 1. Kudus: Universitas Muria Kudus.

Djamarah dan Zain. 2006. Strategi Belajar Mengajar. Jakarta. Rineka Cipta

Hosnan. 2014. Pendekatan Saintifik dan Kontekstual Dalam Pembelajaran Abad 21. Bogor: Ghalia Indonesia. 
Junaidi Arsyad, Ahmad Syukur, M.Toguan,Suhaiman dan Nurbaiti. 2014. Modelmodel PembelajaranTematik dan Strategi Pengembanganya. Diambil dari http//www.cintailmu76.wordpress.com. Diakses tanggal 20 Oktober 2014.

Kemendikbud, 2014. Materi Pelatihan Implementasi Kurikulum 2013. Jakarta: Badan Pengembangan Sumber Daya Manusia Pendidikan dan Kebudayaan dan Penjaminan Mutu Pendidikan Kementerian Pendidikan dan Kebudayaan.

Nyimas, Aisyah. 2008. Pengembangan Pembelajaran Matematika SD. Jakarta: Direktorat Jendral Pendidikan Tinggi.

Suherman, Erman dkk. 2003. Strategi Pembelajaran Matematik Kontemporer. Bandung. Universitas Pendidikan Indonesia.

Umala, Nadhifatul. 2012. Implementasi Model Pembelajaran Open Ended Problem untuk Meningkatkan Prestasi dan Kemampuan Berpikir Kritis Peserta Didik XI IPA MAN Kunir Kabupaten Blitar. Malang. Universitas Malang

Wahyudi dan Kriswandani. 2010. Pengembangan Pembelajaran Matematika SD. Salatiga. UKSW

.2013. Salinan Permendikbud No.65 Tahun 2013 tentang Standar Proses. Jakarta. Kementrian Pendidikan dan Kebudayaan . 